\title{
Three-Year Clinical Outcomes of Patients Treated with Everolimus- Eluting Bioresorbable Vascular Scaffolds: Final Results of the ABSORB EXTEND Trial
}

\begin{abstract}
J Ribamar Costa Jr. MD ${ }^{1}$, PhD; Alexandre Abizaid MD ${ }^{1}$, PhD; Robert Whitbourn $\mathrm{MD}^{2}$, Patrick W Serruys, $\mathrm{MD}^{3}$, $\mathrm{PhD}$, Nigel Jepson $\mathrm{MD}^{4}$, PhD; Clemens Steinwender $\mathrm{MD}^{5}$, Marrianne Stuteville, $\mathrm{BSN}^{6}$, Divine Ediebah, $\mathrm{MSC}^{6}$, Krishnankutty Sudhir, $\mathrm{MD}, \mathrm{PhD}^{7}$, Antonio L. Bartorelli $\mathrm{MD}^{8}$, on behalf of the ABSORB EXTEND investigators

${ }^{1}$ Instituto de Cardiologia Dante Pazzanese, Sao Paulo, Brazil, ${ }^{2}$ St Vincent's Hospital, Fitzroy, Victoria, Australia, ${ }^{3}$ Thoraxcenter, Erasmus University Medical Center, Rotterdam, The Netherlands, ${ }^{4}$ Prince of Wales Public, Sydney Australia, ${ }^{5}$ Allgemeines Krankenhaus Linz, Linz, Austria, ${ }^{6}$ Abbott Vascular, Diegem, Belgium, ${ }^{7}$ Abbott Vascular, Santa Clara, USA; ${ }^{8}$ Centro Cardiologico Monzino, IRCCS, University of Milan, Milan, Italy
\end{abstract}

Short title: Final results of the ABSORB Extend trial

Conflict of interest: Marrianne Stuteville, Divine Ediebah and Krishnankutty Sudhir are full time employees at Abbott Vascular

Total number of words: 3234 (including references and figure legends)

\section{Correspondence to:}

Alexandre Abizaid., MD, PhD

Av. Dr. Dante Pazzanese, 500 - Vila Mariana - São Paulo, SP, Brasil

CEP 04012-180

e-mail: aabizaid@uol.com.br

This is the author manuscript accepted for publication and has undergone full peer review but has not been through the copyediting, typesetting, pagination and proofreading process, which may lead to differences between this version and the Version of Record. Please cite this article as doi: $10.1002 / \operatorname{ccd} .27715$

This article is protected by copyright. All rights reserved. 


\section{ABSTRACT}

Background: There is still limited data on the very long term clinical outcomes after ABSORB BRS in daily practice. We sought to evaluate the 3 year-performance of the Absorb BVS for the treatment of low/moderate complexity patients enrolled in the ABSORB EXTEND trial.

Methods: ABSORB EXTEND is a prospective, single-arm, open-label clinical study in which 812 patients were enrolled at 56 sites. This study allowed the treatment of lesions $\leq 28 \mathrm{~mm}$ in length and reference vessel diameter of $2.0-3.8 \mathrm{~mm}$ (as assessed by on-line QCA). In order to determine the independent predictors of MACE, a multivariable logistic regression model was built using a stepwise (forward/backward) procedure.

Results: Average population age was 61 years and 26.5\% had diabetes. Most patients had single target lesion (92.4\%). Adequate scaffold deployment (PSP) was achieved in $14.2 \%$ of the cases. At three years, the composite endpoints of MACE and ischemiadriven target vessel failure were $9.2 \%$ and $10.6 \%$, respectively. The cumulative rate of ARC definite/probable thrombosis was $2.2 \%$, with $1.2 \%$ of the cases occurring after the $1^{\text {st }}$ year. Independent predictors of MACE were hypertension and the need for "bail out" stent.

Conclusion: At three-year follow-up, the use of ABSORB in low/moderate complex PCI was associated with low and acceptable rates of major adverse clinical events, despite the infrequent use of the recommended contemporary scaffold deployment technique. However, scaffold thrombosis rate was higher than reported with current generation of

This article is protected by copyright. All rights reserved. 
metallic DES. The study is registered on clinicaltrials.gov (unique identifier NCT01023789).

Key words: bioresorbable scaffold, everolimus, thrombosis

\section{Introduction}

Despite the attractive concept of "vessel uncaging and vascular restoration" that prompted the development of bioresorbable vascular scaffolds (BVS), recent randomized trials and "real-world" registries have raised concern about the safety of the $1^{\text {st }}$ generation of this novel technology, especially due to increased risk of thrombosis within the first weeks of the scaffold implantation ${ }^{1-4}$ and also lately, after the $1^{\text {st }}$ year of follow-up ${ }^{5-8}$, when mechanical properties of the BVS were expected to have disappeared or markedly attenuated $^{9}$.

While early events seem to be closely related to lesion selection (e.g: treatment of small vessels) and poor deployment technique (e.g.: inadequate vessel sizing, under expansion, etc.), few is known about the real incidence and mechanisms behind the late events ( $>1$ year), since there is a paucity of long term data on these devices.

We sought to evaluate the late (3 years) performance of the Absorb BVS for the treatment of low/moderate complexity patients enrolled in the ABSORB EXTEND trial.

\section{METHODS}

\section{Study Population}

This article is protected by copyright. All rights reserved. 
In the present analysis, we included all patients enrolled in the ABSORB EXTEND trial. The details of this study have been described elsewhere ${ }^{10,11}$. In brief, this was a prospective, single-arm, open-label clinical trial that enrolled 812 patients at 56 international sites outside of the US. Target arteries should have a reference vessel diameter (RVD) $\geq 2.0 \mathrm{~mm}$ and $\leq 3.8 \mathrm{~mm}$, a maximum lesion length of $\leq 28 \mathrm{~mm}$, a diameter stenosis $\geq 50 \%$ and $<100 \%$. A maximum of two de novo native coronary artery lesions could be treated, each located in a different major epicardial vessel. Major exclusion criteria included a recent MI ( $<72$ hours before the index procedure) and target lesions located in the left main or within an arterial or saphenous vein graft.

Abbott Vascular (Santa Clara, CA, US) funded the study. The research ethics committee of each participating institution approved the protocol and all enrolled patients provided written informed consent before inclusion. The study is registered on clinicaltrials.gov (unique identifier NCT01023789).

\section{Study End Points and Definitions}

The primary end point of this study was the three-year composite MACE rate, including cardiac death, non-fatal myocardial infarction (MI), and ischemia-driven target lesion revascularization (TLR). Additionally, we report the long-term rates of target vessel failure (TVF) and scaffold thrombosis.

Device and clinical success have been previously defined, as well as TVF, cardiac death, non-fatal MI and ischemia-driven target vessel failure (ID-TVF). Device thrombosis was categorized as acute ( $<1$ day), subacute (1-30 days) and late ( $>30$ days) and was defined according to the ARC guidelines.

"Bail out" scaffold/stent was the use of additional, unplanned device to treat a complication related to the implant of the BVS (e.g edge dissection). This registry allowed the use of either another BVS or a metallic stent as "bail out", being the decision at operator's discretion.

This article is protected by copyright. All rights reserved. 
Adequate scaffold implantation (PSP) criteria, although not available at the time of the ABSORB Extend Registry enrollment, was defined as below and retrospectively assessed by an independent corelab:

i. patients with pre-dilatation;

ii. QCA reference vessel diameter $\geq 2.25 \mathrm{~mm}-\leq 3.5 \mathrm{~mm}$;

iii. post-dilatation performed at $\geq 18$ atm, with non-compliant balloon diameter $>$ nominal scaffold diameter but $\leq$ nominal scaffold diameter + $0.5 \mathrm{~mm}$.

\section{Statistical Analysis}

For the descriptive statistics, categorical data are presented as counts and percentages and continuous variables are presented as mean \pm standard deviation (SD).

To determine the independent predictors of MACE, a multivariable logistic regression model was built using a stepwise (forward/backward) procedure, with independent variables entered the model at the 0.20 significance level and removed at the 0.10 level. Variables were eligible for inclusion in the multivariable logistic regression model-building process if the variable was present for $90 \%$ of the subjects in the analyses, they had a p-value $<0.2$ from the univariable analysis, and if highly correlated with another variable $(r>0.5$ and $p<0.05)$, had the higher level of significance.

Time-to-event variables are presented as Kaplan-Meier curves. A two-tailed p value $<0.05$ was considered statistically significant.

\section{RESULTS}

\section{Baseline population and angiographic characteristics}

A total of 812 patients were enrolled in the ABSORB EXTEND Single Arm Trial between $11^{\text {th }}$ January 2010 to $2^{\text {nd }}$ October 2013. Mean population age was $61.1 \pm 10.7$ and

This article is protected by copyright. All rights reserved. 
most patients were male (74.3\%). Diabetes mellitus was present in $26.5 \%$ of the cohort. Acute coronary syndrome (unstable angina / non-ST elevation MI) was the initial clinical presentation in $43.2 \%$ of the cases (table 1 ).

Table 2 displays the most relevant angiographic findings. Most patients had a single lesion treated (92.4\%), being the LAD the target vessel in $45.2 \%$ of the cases. Overlapping was required in $10.5 \%$ of the procedures. Mean reference vessel diameter and lesion length were $2.64 \pm 0.39 \mathrm{~mm}$ and $12.5 \pm 5.3 \mathrm{~mm}$, respectively. As per protocol, pre-dilatation was performed in almost all cases in the ABSORB EXTEND patients (99.7\%). Post dilation was performed in $68.8 \%$ of the cases. Notably, adequate scaffold implantation (PSP) was achieved in only $14.2 \%$ of the entire cohort. Need for "bail out" scaffold/stent occurred in $4.2 \%$ of the procedures, being $2.2 \%$ performed with the implant of an additional BVS.

\section{Clinical events}

Table 3 shows the cumulative incidence of clinical adverse events at 30 days, 1 and 3 years. Three-year clinical follow-up was available for all patients. Of n ote, $40 \%$ of all patients were still under DAPT at three years. As noted, the cumulative incidences of hierarchical MACE (9.2\%) and TVF (10.6\%) were relatively low during the entire follow-up, being mostly driven by peri procedural MI in the first 30 days and by ischemia-driven TLR in the remaining period. The cumulative incidence of definite/probable scaffold thrombosis at 30 days, 1 and 3 years was $0.6 \%, 1.0 \%$ and $2.2 \%$, respectively.

Figure 1 shows the cumulative incidence of MACE (panel A), and TVF (panel B). figure 2 displays the KM curves for cardiac death (panel A), non-fatal MI (panel B), ischemia -driven TLR (panel C) and definite/probable device thrombosis (panel D).

Figure 3 displays a landmark analysis of MACE (panel A) and definite/probable device thrombosis (panel B). As observed, half of the events occurred between 1 and 3

This article is protected by copyright. All rights reserved. 
years of follow-up $\left(0.5 \%\right.$ between the $1^{\text {st }}$ and $2^{\text {nd }}$ year and $0.6 \%$ between the $2^{\text {nd }}$ and $3^{\text {rd }}$ year).

Adequate scaffold implantation (PSP) did not impact the MACE rate after ABSORB implantation in this Extend registry (figure 4). However, of the eight cases of very late scaffold thrombosis, seven occurred among patients who did not fulfilled the PSP criteria. Since the vast majority of the cases did not achieve PSP, this variable was not found as a predictor of negative outcomes in the trial, but the importance of achieving an adequate scaffold implantation should not be minimized by this finding.

\section{Multivariate analysis}

The only independent predictors of MACE were hypertension (OR 2.26, 95\% CI: 1.18 - 4.32, $\mathrm{p}=0.01$ ) and use of "bail out" stent (OR 3.32, 95\% CI:1.37, 8.05, p= 0.008).

Since cardiac death, TLR and scaffold thrombosis were relatively low frequency events, it was not possible to estimate their independent predictors with reasonable accuracy.

\section{DISCUSSION}

The current study shows a relatively low rate of MACE and ischemia-driven TVF among low/moderate patients treated with ABSORB up to 3 years of follow-up. Notably, half of the scaffold thrombosis cases occurred after the $1^{\text {st }}$ year of the index procedure.

Six randomized clinical trials (ABSORB II, ABSORB III, ABSORB China, ABSORB Japan, and EVERBIO II and AIDA) ${ }^{12-17}$ comparing the Absorb BVS with everolimus-eluting metallic stent (EES) have been conducted, including a total of 5,583 patients. The results of each study suggested that, in the midterm clinical follow up $(\leq 2$ years), there were no differences in the revascularization measures of efficacy (e.g:

This article is protected by copyright. All rights reserved. 
ischemia-driven TLR and TVR) between devices, which was confirmed in a patient-level metanalysis including most of these trials ${ }^{3}$.

Nevertheless, the same meta-analysis has identified an increase in the risk of target-vessel myocardial infarction with Absorb BVS compared with EES (relative risk, 1.45 [1.02-2.07]; $\mathrm{P}=0.04$ ), mainly because of periprocedural myocardial infarction (relative risk, 1.29 [0.82-2.03]; $\mathrm{P}=0.27$ ) and device thrombosis (relative risk, 2.09 [0.924.75]; $\mathrm{P}=0.08$ ) within the first year after the index procedure ${ }^{3}$.

More recently, 3 years results of the randomized ABSORB China trial did not point to a significant difference in TLF and thrombosis between these devices ${ }^{18}$. On the other hand, a larger randomized trial, with more complex population (ABSORB 3) showed a three times higher thrombosis rate with the ABSROB at three years ( $2.3 \%$ vs. $0.7 \%$; $<0.01)^{19}$. More disturbing, a very recent individual-patient-data meta-analysis of three-year outcomes of ABSORB vs Xience from the ABSORB randomized trials showed higher rates of target lesion failure (11.7\% versus $8.1 \%$; risk ratio [RR], 1.38; 95\% confidence interval $[\mathrm{CI}], 1.10-1.73 ; \mathrm{P}=0.006)$, driven by greater target vessel myocardial infarction (7.8\% versus 4.2\%; RR, 1.72; 95\% CI, 1.26-2.35; $\mathrm{P}=0.0006)$ and ischemia-driven target lesion revascularization (6.6\% versus 4.4\%; RR, 1.44; 95\% CI, 1.05-1.98; $\mathrm{P}=0.02)$, with comparable cardiac mortality ( $1.1 \%$ versus $1.1 \%$; $\mathrm{RR}, 0.93$; 95\% CI, 0.47-1.88; $\mathrm{P}=0.85$ ). Device thrombosis rates through 3 years were also higher with BVS (2.4\% versus 0.6\%; RR, 3.71; 95\% CI, 1.70-8.11; $\mathrm{P}=0.001)^{20}$. The rate of scaffold thrombosis in this studies was very similar to the reported in the current manuscript at the same follow-up interval.

Plausible mechanisms of the early thrombotic hazard observed with Absorb BVS included rheological alterations caused by the thick struts of the scaffold, as well as technical factors during implantation, including lack of adequate vessel sizing and proper scaffold expansion. Based on these findings, current recommendation for BVS implantation include a recommendation for routine high pressure post dilation and more 
liberal use of intravascular imaging modalities (IVUS/OCT) to guide adequate device selection and implantation. Of note, in the present analysis, most of the in-hospital MACE was also driven by peri procedure MI. However, the one-year scaffold thrombosis rate was relatively low $(1,0 \%)$ and comparable to most $2^{\text {nd }}$ generation metallic DES in studies with similar population and lesion profiles.

Recently, Collet et al. published a metanalysis with the late clinical outcomes ( $>2$ years) of 1,730 patients treated either with either ABSORB BVS or metallic EES from five randomized clinical trials ${ }^{6}$. Patients treated with the scaffold had a higher risk of definite/probable thrombosis compared with patients treated with metallic DES (OR 2.93, 95\% CI 1.37-6.26, $\mathrm{P}=0.01$ ). Furthermore, these patients had a trend towards higher risk of TLF (OR 1.48, 95\%CI 0.90-2.42, P = 0.09), driven by a higher risk of target vessel myocardial infarction and ischemia-driven target lesion revascularization. No difference was found in the risk of cardiac death. In the ISAR-ABSORB registry, Wiebe et al, showed a $1.3 \%$ rate of definite/probable BVS thrombosis between the $1^{\text {st }}$ and $2^{\text {nd }}$ year of follow up ${ }^{21}$. Similarly, in the Extend Registry, ABSORB definite/probable thrombosis rate was of $1.2 \%$ after the $1^{\text {st }}$ year of the procedure.

At present, while the causes of acute BVS failure are better understood, the possible mechanism behind late failure of these devices are still not completely understood. Most of the present knowledge is based on retrospective analysis from case reports using intravascular imaging, especially OCT. Among the postulated causes the most frequent observed are: 1) strut malapposition (either persistent or late acquired); 2) late device discontinuity, which is a programmed phenomenon in the bioresorption process of the polymeric device; 3) peri strut low-intensity area on OCT; 4) delayed vessel healing, and; 5) neoatherosclerosis ${ }^{22-25}$.

Dual antiplatelet therapy (DAPT) has a key importance in the prevention of thrombotic events after BVS. The absence of DAPT is the single most powerful predictor of thrombosis within the $1^{\text {st }}$ year of the procedure. Notably, in Collet's 
metanalysis, $92 \%$ of the BVS thrombosis after the $1^{\text {st }}$ year occurred among patients who had discontinued DAPT ${ }^{6}$. However, it is not clear whether to prolong these medications would prevent the occurrence of this untoward event. Nevertheless, many services around the world are recommending DAPT for at least two years in patients treated with $\mathrm{ABSORB}^{8}$. In our registry, less than half of the entire cohort was on DAPT after the $1^{\text {st }}$ year.

\section{Limitations}

This study was limited by the single-arm nature of the design and the inherent lack of a control arm for direct comparison. Also, the lack of systematic invasive evaluation, with use of intravascular imaging (IVUS or OCT), precludes more definite conclusions about the mechanisms related to BVS failure at different timepoints.

\section{Conclusions}

At three-year follow-up, the use of ABSORB in non-complex PCI was associated with low and acceptable rates of major adverse clinical events, despite the infrequent use of the recommended contemporary scaffold deployment technique. However, the incidence of scaffold thrombosis was higher than the reported for the current generation of DES.

\section{References:}

1. Capodanno D, Gori T, Nef H, Latib A, Mehilli J, Lesiak M, Caramanno G, Naber C, Di Mario C, Colombo A, Capranzano P, Wiebe J, Araszkiewicz A, Geraci S, Pyxaras S, Mattesini A, Naganuma T, Münzel T, Tamburino C. Percutaneous coronary intervention with everolimus-eluting bioresorbable vascular scaffolds in routine clinical

This article is protected by copyright. All rights reserved. 
practice: early and midterm outcomes from the European multicentre GHOST-EU registry. EuroIntervention. 2015 Feb;10(10):1144-53.

2. Lipinski MJ, Escarcega RO, Baker NC, Benn HA, Gaglia MA Jr, Torguson R, Waksman R. Scaffold Thrombosis After Percutaneous Coronary Intervention With ABSORB Bioresorbable Vascular Scaffold: A Systematic Review and Meta-Analysis. JACC Cardiovasc Interv. 2016 Jan 11;9(1):12-24.

3. Stone GW, Gao R, Kimura T, Kereiakes DJ, Ellis SG, Onuma Y, Cheong WF, Jones-McMeans J, Su X, Zhang Z, Serruys PW. 1-year outcomes with the Absorb bioresorbable scaffold in patients with coronary artery disease: a patient-level, pooled meta-analysis. Lancet. 2016 Mar 26;387(10025):1277-89.

4. Cassese S, Byrne RA, Ndrepepa G, Kufner S, Wiebe J, Repp J, Schunkert H, Fusaro M, Kimura T, Kastrati A. Everolimus-eluting bioresorbable vascular scaffolds versus everolimus-eluting metallic stents: a meta-analysis of randomised controlled trials. Lancet. 2016 Feb 6;387(10018):537-44.

5. Räber L, Brugaletta S, Yamaji K, O'Sullivan CJ, Otsuki S, Koppara T, Taniwaki M, Onuma Y, Freixa X, Eberli FR, Serruys PW, Joner M, Sabaté M, Windecker S. Very Late Scaffold Thrombosis: Intracoronary Imaging and Histopathological and Spectroscopic Findings. J Am Coll Cardiol. 2015 Oct 27;66(17):1901-14.

6. Collet C, Asano T, Miyazaki Y, Tenekecioglu E, Katagiri Y, Sotomi Y, Cavalcante R, de Winter RJ, Kimura T, Gao R, Puricel S, Cook S, Capodanno D, Onuma Y, Serruys PW. Late thrombotic events after bioresorbable scaffold implantation: a

This article is protected by copyright. All rights reserved. 
systematic review and meta-analysis of randomized clinical trials. Eur Heart J. 2017. [Epub ahead of print].

7. Ali ZA, Serruys PW, Kimura T, Gao R, Ellis SG, Kereiakes DJ, Onuma Y, Simonton C, Zhang Z, Stone GW. 2-year outcomes with the Absorb bioresorbable scaffold for treatment of coronary artery disease: a systematic review and meta-analysis of seven randomised trials with an individual patient data substudy. Lancet. 2017 [Epub ahead of print].

8. Felix CM, Vlachojannis GJ, IJsselmuiden AJJ, Fam JM, Smits PC, Lansink WJ, Diletti R, Zijlstra F, Regar ES, Boersma E, Onuma Y, van Geuns RJM. Potentially increased incidence of scaffold thrombosis in patients treated with Absorb BVS who terminated DAPT before 18 months. EuroIntervention. 2017 Jun 2;13(2):e177-e184.

9. Dudek D, Rzeszutko Ł, Onuma Y, Sotomi Y, Depukat R, Veldhof S, Ediebah D, Staehr P, Zasada W, Malinowski KP, Kaluza GL, Serruys PW. Vasomotor Response to Nitroglycerine Over 5 Years Follow-Up After Everolimus-Eluting Bioresorbable Scaffold Implantation. JACC Cardiovasc Interv. 2017 Apr 24;10(8):786-795.

10. Abizaid A, Ribamar Costa J Jr, Bartorelli AL, Whitbourn R, van Geuns RJ, Chevalier B, Patel T, Seth A, Stuteville M, Dorange C, Cheong WF, Sudhir K, Serruys PW; ABSORB EXTEND investigators. The ABSORB EXTEND study: preliminary report of the twelve-month clinical outcomes in the first 512 patients enrolled. EuroIntervention. 2015 Apr;10(12):1396-401.

11. de Ribamar Costa J Jr, Abizaid A, Bartorelli AL, Whitbourn R, Jepson N, Perin M, Steinwender C, Stuteville M, Ediebah D, Sudhir K, Serruys PW. One-year clinical outcomes of patients treated with everolimus-eluting bioresorbable vascular scaffolds

This article is protected by copyright. All rights reserved. 
versus everolimus-eluting metallic stents: a propensity score comparison of patients enrolled in the ABSORB EXTEND and SPIRIT trials. EuroIntervention. 2016 Nov 20;12(10):1255-1262

12. Serruys PW, Chevalier B, Dudek D, Cequier A, Carrie D, Iniguez A, Dominici M, van der Schaaf RJ, Haude M, Wasungu L, Veldhof S, Peng L, Staehr P, Grundeken MJ, Ishibashi Y, Garcia-Garcia HM, Onuma Y. A bioresorbable everolimus-eluting scaffold versus a metallic everolimus-eluting stent for ischaemic heart disease caused by de-novo native coronary artery lesions (ABSORB II): an interim 1-year analysis of clinical and procedural secondary outcomes from a randomised controlled trial. Lancet 2015;385:4354.

13. Ellis SG, Kereiakes DJ, Metzger DC, Caputo RP, Rizik DG, Teirstein PS, Litt MR, Kini A, Kabour A, Marx SO, Popma JJ, McGreevy R, Zhang Z, Simonton C, Stone GW, Investigators AI. Everolimus-eluting bioresorbable scaffolds for coronary artery disease. N Engl J Med 2015;373:1905-1915.

14. Gao R, Yang Y, Han Y, Huo Y, Chen J, Yu B, Su X, Li L, Kuo HC, Ying SW, Cheong WF, Zhang Y, Su X, Xu B, Popma JJ, Stone GW. Bioresorbable vascular scaffolds versus metallic stents in patients with coronary artery disease: ABSORB China Trial. J Am Coll Cardiol 2015;66:2298-2309.

15. Kimura T, Kozuma K, Tanabe K, Nakamura S, Yamane M, Muramatsu T, Saito S, Yajima J, Hagiwara N, Mitsudo K, Popma JJ, Serruys PW, Onuma Y, Ying S, Cao S, Staehr P, Cheong WF, Kusano H, Stone GW. A randomized trial evaluating everolimuseluting Absorb bioresorbable scaffolds vs. everolimus-eluting metallic stents in patients with coronary artery disease: ABSORB Japan. Eur Heart J 2015;36:3332-3342.

This article is protected by copyright. All rights reserved. 
16. Puricel S, Arroyo D, Corpataux N, Baeriswyl G, Lehmann S, Kallinikou Z, Muller O, Allard L, Stauffer JC, Togni M, Goy JJ, Cook S. Comparison of everolimusand biolimus-eluting coronary stents with everolimus-eluting bioresorbable vascular scaffolds. J Am Coll Cardiol 2015;65:791-801.

17. Wykrzykowska JJ, Kraak RP, Hofma SH, van der Schaaf RJ, Arkenbout EK, IJsselmuiden AJ, Elias J, van Dongen IM, Tijssen RYG, Koch KT, Baan J Jr, Vis MM, de Winter RJ, Piek JJ, Tijssen JGP, Henriques JPS; AIDA Investigators. Bioresorbable Scaffolds versus Metallic Stents in Routine PCI. N Engl J Med. 2017 Jun $15 ; 376(24): 2319-2328$.

18. Xu B, Yang Y, Han Y, Huo Y, Wang L, Qi X, Li J, Chen Y, Kuo HC, Ying SW, Cheong WF, Zhang Y, Su X, Popma JJ, Gao R, Stone G. Comparison of everolimuseluting bioresorbable vascular scaffolds and metallic stents: three-year clinical outcomes from the ABSORB China randomised trial. EuroIntervention. 2017 Oct 22. pii: EIJ-D-1700796.

19. Kereiakes DJ, Ellis SG, Metzger C, Caputo RP, Rizik DG, Teirstein PS, Litt MR, Kini A, Kabour A, Marx SO, Popma JJ, McGreevy R, Zhang Z, Simonton C, Stone GW; ABSORB III Investigators. 3-Year Clinical Outcomes With Everolimus-Eluting Bioresorbable Coronary Scaffolds: The ABSORB III Trial. J Am Coll Cardiol. 2017 Dec 12;70(23):2852-2862.

20. Ali ZA, Gao R, Kimura T, Onuma Y, Kereiakes DJ, Ellis SG, Chevalier B, Vu MT, Zhang Z, Simonton CA, Serruys PW, Stone GW. Three-Year Outcomes With the

This article is protected by copyright. All rights reserved. 
Absorb Bioresorbable Scaffold: Individual-Patient-Data Meta-Analysis From the ABSORB Randomized Trials. Circulation. 2018 Jan 30;137(5):464-479.

21. Wiebe J, Hoppmann P, Colleran R, Kufner S, Valeskini M, Cassese S, Schneider S, Joner M, Schunkert H, Laugwitz KL, Kastrati A, Byrne RA. Long-Term Clinical Outcomes of Patients Treated With Everolimus-Eluting Bioresorbable Stents in Routine Practice: 2-Year Results of the ISAR-ABSORB Registry. JACC Cardiovasc Interv. 2017 Jun 26;10(12):1222-1229.

22. Cuculi F, Puricel S, Jamshidi P, Valentin J, Kallinikou Z, Toggweiler S, Weissner M, Munzel T, Cook S, Gori T. Optical coherence tomography findings in bioresorbable vascular scaffolds thrombosis. Circ Cardiovasc Interv 2015;8:e002518.

23. Puricel S, Cuculi F, Weissner M, Schmermund A, Jamshidi P, Nyffenegger T, Binder H, Eggebrecht H, Munzel T, Cook S, Gori T. Bioresorbable coronary scaffold thrombosis: multicenter comprehensive analysis of clinical presentation, mechanisms, and predictors. J Am Coll Cardiol 2016;67:921-931.

24. Sotomi Y, Suwannasom P, Serruys PW, Onuma Y. Possible mechanical causes of scaffold thrombosis: insights from case reports with intracoronary imaging. EuroIntervention 2017;12:1741-1756.

25. Onuma Y, Sotomi Y, Shiomi H, Ozaki Y, Namiki A, Yasuda S, Ueno T, Ando K, Furuya J, Igarashi K, Kozuma K, Tanabe K, Kusano H, Rapoza R, Popma JJ, Stone GW, Simonton C, Serruys PW, Kimura T. Two-year clinical, angiographic, and serial optical coherence tomographic follow-up after implantation of an everolimus-eluting

This article is protected by copyright. All rights reserved. 
bioresorbable scaffold and an everolimus-eluting metallic stent: insights from the randomised ABSORB Japan trial. EuroIntervention 2016;12: 1090-1101.

\section{Figure Legend}

Figure 1. Kaplan-Meir survival curves of MACE (panel A) and target-vessel failure (panel B)

Figure 2. Kaplan-Meir survival curves of cardiac death (panel A), non-fatal myocardial infarction (panel B), ischemia-driven TLR (panel C), and definite/probable scaffold thrombosis (panel D).

Figure 3. Kaplan-Meir landmark survival curves of MACE (panel A) and definite/probable scaffold thrombosis (panel B). As observed, half of the negative events occurred after the first year of follow-up.

Figure 4. Impact of adequate scaffold implantation (PSP) in the late outcomes after ABSORB implantation.

This article is protected by copyright. All rights reserved. 


\section{University Library}

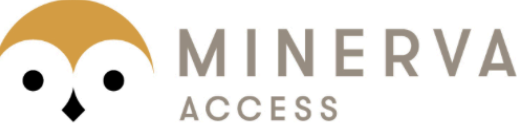

A gateway to Melbourne's research publications

Minerva Access is the Institutional Repository of The University of Melbourne

Author/s:

Ribamar Costa, J;Abizaid, A;Whitbourn, R;Serruys, PW;Jepson, N;Steinwender, C;Stuteville, M;Ediebah, D;Sudhir, K;Bartorelli, AL

Title:

Three-year clinical outcomes of patients treated with everolimus-eluting bioresorbable vascular scaffolds: Final results of the ABSORB EXTEND trial

Date:

2019-01-01

Citation:

Ribamar Costa, J., Abizaid, A., Whitbourn, R., Serruys, P. W., Jepson, N., Steinwender, C., Stuteville, M., Ediebah, D., Sudhir, K. \& Bartorelli, A. L. (2019). Three-year clinical outcomes of patients treated with everolimus-eluting bioresorbable vascular scaffolds: Final results of the ABSORB EXTEND trial. CATHETERIZATION AND CARDIOVASCULAR INTERVENTIONS, 93 (1), pp.E1-E7. https://doi.org/10.1002/ccd.27715.

Persistent Link:

http://hdl.handle.net/11343/284644 